\title{
Efficacy and Application Methods of Oxathiapiprolin for Management of Black Shank on Tobacco
}

Pingsheng Ji, Alexander S. Csinos, Lara L. Hickman, and Unessee Hargett, Department of Plant Pathology, Coastal Plain Experiment Station, University of Georgia, Tifton 31794

\begin{abstract}
Ji, P., Csinos, A. S., Hickman, L. L., and Hargett, U. 2014. Efficacy and application methods of oxathiapiprolin for management of black shank on tobacco. Plant Dis. 98:1551-1554.

Black shank, caused by Phytophthora nicotianae, is responsible for serious yield and quality reduction in tobacco production. Application of effective fungicides continues to be a viable component in developing integrated disease management programs. Experiments were conducted in 2011 to 2013 to determine the efficacy and application methods of a new fungicide, Zorvec (a.i. oxathiapiprolin), for management of black shank under field conditions. Oxathiapiprolin is the first member of a new class of isoxazoline fungicide. Application of Zorvec ( 0.35 liter/ha) onto tobacco seedlings 1 week prior to transplanting in conjunction with directed applications of the product at 0.7 liter/ha at first cultivation and lay-by (last cultivation) reduced black shank sig-

nificantly compared to the nontreated control in the experiments conducted in 2011 and 2012. Application of Zorvec at 1.4 liter/ha through transplant water followed by directed sprays at first cultivation and layby at 0.7 liter/ha reduced black shank significantly compared with the nontreated control in 2012 and 2013 studies. These treatments were not significantly different $(P=0.05)$ in disease reduction compared to mefenoxam. All treatments involving Zorvec increased tobacco yield significantly $(P=0.05)$ or showed a tendency to increase tobacco yield over the nontreated control in all experiments conducted in 2011 to 2013. The results indicated that the new fungicide oxathiapiprolin was effective in reduction of $P$. nicotianae on tobacco.
\end{abstract}

Black shank, caused by the soilborne oomycete pathogen Phytophthora nicotianae (Breda de Haan) (syn. Phytophthora parasitica var. nicotianae), is a devastating disease on tobacco (Nicotiana tabacum L.) in Georgia and many other tobacco producing areas worldwide $(5,14)$. The pathogen infects roots, stems, and leaves at all growing stages of the tobacco plant, resulting in significant yield and quality reduction $(8,19)$. Tobacco plants infected early in the season may be stunted and collapse before leaves become mature for harvest $(5,8)$. Common symptoms include plant wilting and chlorosis, black lesions on roots and stems, and piths turning brown or black and separated into plate-like disks $(3,19)$. The disease is favored by wet and humid weather conditions that are common in the southeastern United States.

Black shank is among the most difficult diseases to control. Crop rotation is of limited value due to long-term survival of the pathogen in the soil and is not commonly adopted by growers. A challenge in managing black shank is the diversity of $P$. nicotianae. Four physiological races $(0,1,2$, and 3$)$ of $P$. nicotianae were reported, and three races $(0,1$, and 3$)$ have been found in the United States $(2,5,10,13,15,16,23)$. Tobacco cultivars resistant to race 0 of $P$. nicotianae conferred by the gene $P h p$ or $P h l$ have been widely used; however, the gradual shift of pathogen populations from race 0 to race 1 makes the cultivars resistant to race 0 ineffective in disease control $(4,5,21)$. Integrated use of different resistant tobacco cultivars and effective fungicides has been recommended for management of the disease $(1,4,21)$.

Application of fungicides continues to be an effective approach in managing black shank. Products containing mefenoxam or metalaxyl (a.i. mefenoxam) have been the most widely used fungicides for control of $P$. nicotianae. However, field isolates of $P$. nicotianae were variable in sensitivity to metalaxyl, and typical field rates may not be sufficient to control isolates with low levels of sensitiv-

Corresponding author: P. Ji, E-mail: pji@uga.edu

Accepted for publication 30 April 2014.

http://dx.doi.org/10.1094/PDIS-02-14-0172-RE

(C) 2014 The American Phytopathological Society ity (5). In addition, continuous use of a single fungicide enhanced selection of $P$. nicotianae populations less sensitive to the compound (18). Identifying new active ingredients to be used as alternative or complementary approaches is desirable for improving disease control and reducing selection pressure for fungicide resistance development. Oxathiapiprolin (Zorvec) is the first of the new isoxazoline class of fungicides discovered and developed by DuPont Crop Protection (Wilmington, DE) for control of oomycete pathogens (17). The objective of this study was to evaluate the efficacy and field application methods of oxathiapiprolin for managing black shank on tobacco.

\section{Materials and Methods}

Field preparation. The experiments were conducted at the University of Georgia Coastal Plain Experiment Station located in Tifton, GA, in 2011 to 2013. The experimental field had a continuous history of black shank on tobacco in previous years. The field was prepared by disc harrowing and tilling with stine tiller. Before transplanting tobacco, 4-8-12 N-P-K was broadcast applied at 560 $\mathrm{kg} / \mathrm{ha}$ and tilled in. Plots were subsoiled and bedded after fertilizer application. Additional fertilizers, $729 \mathrm{~kg} / \mathrm{ha}$ of $15.5-0-0$ calcium nitrate, were applied after transplanting. Pesticides were applied for insect and nematode control before and after transplanting according to University of Georgia cooperative extension recommendations.

Tobacco plants. Tobacco (cv. K326) was grown from seeds in Styrofoam trays with $2.5 \times 2.5 \mathrm{~cm}$ cells containing a commercial potting mix (Miracle-Gro LLC, Marysville, $\mathrm{OH}$ ) and maintained in a greenhouse. Two-month-old seedlings were either treated or not treated with Zorvec in the greenhouse 1 week before transplanting into the field. Each plot in the field consisted of a single row which was $9.8 \times 1.22 \mathrm{~m}$. The seedlings were planted at $46-\mathrm{cm}$ spacing with 23 plants in a plot, and 3-m alleys were maintained between plots. A randomized complete block design was employed with five replicates. Tobacco was topped and suckered about 2 months after transplanting in the field.

Application of oxathiapiprolin. In 2011, oxathiapiprolin was applied at different rates and by different methods (Table 1). One week before transplanting in the field, tobacco plants in seedling trays were sprayed in the greenhouse with Zorvec at 0.35 liter/ha 
(0.35 liter/3,500 plants) using a handheld $\mathrm{CO}_{2}$-powered sprayer for soil and root drench. To apply Zorvec through transplant water at transplanting, the product was applied at 0.35 liter/ha using a $\mathrm{CO}_{2-}$ powered sprayer delivering the chemical directly into the transplant water and plant furrow. Band application of Zorvec was made 7 days after transplanting at 2.8 liter/ha using a $\mathrm{CO}_{2}$-powered sprayer. Additional applications of Zorvec included directed sprays using a $\mathrm{CO}_{2}$-powered sprayer at first cultivation and lay-by (last cultivation) at $0.35,0.7,1.4$, and 2.8 liter/ha. Nontreated plots and Ridomil Gold (a.i. mefenoxam) applied at 1.17 liter/ha were used as controls.

In 2012, Zorvec applied through transplant water alone was compared with application through transplant water plus directed sprays at first cultivation and lay-by. Zorvec was applied through transplant water at $0.7,1.4$, and 2.8 liter/ha and sprayed at 0.7 liter/ha at first cultivation and lay-by (Table 2). Zorvec sprayed on tobacco seedlings in the greenhouse $(0.35 \mathrm{liter} / \mathrm{ha})$ in conjunction with directed applications at first cultivation and lay-by (0.7 liter/ha), which reduced black shank significantly in the 2011 experiment, was repeated and used as a control in 2012. Ridomil Gold (0.57 liter/ha) or Zorvec (0.7 liter/ha) applied through transplant water in conjunction with applications of Ridomil Gold at first cultivation and lay-by (1.17 liter/ha), as well as nontreated plots, were also used as controls.

Three treatments evaluated in 2012 were further evaluated in a 2013 field study (Table 3). The treatments included Zorvec applied through transplant water (1.4 liter/ha) and at first cultivation and lay-by (0.7 liter/ha), Ridomil Gold applied through transplant water (0.57 liter/ha) and at first cultivation and lay-by (1.17 liter/ha), and Zorvec applied through transplant water at 2.8 liter/ha. Nontreated plots were used as a control.
Disease and yield assessment and statistical analysis. Plants showing symptoms of black shank disease were sampled for isolation of $P$. nicotianae on pimaricin-ampicillin-rifampicin-pentachloronitrobenzene (PARP) semiselective medium (11). Isolates presumed to be $P$. nicotianae were further confirmed based on morphological characteristics $(9,24)$. Diseased plants were counted and disease incidence was quantified as percent diseased plants. Leaves were harvested from plants three times each year as they ripened. Dry weight yield was calculated as previously reported (7) with the modification that green weight was multiplied by 0.15 , not 0.2 , to obtain dry weight based on our dry weight/green weight conversion studies during the experiment course (A. S. Csinos and P. Ji, unpublished). Disease and yield data were analyzed using GLM procedures of the Statistical Analysis System (SAS Institute), and treatment means were separated by Fisher's protected least significant difference (LSD) test $(P=0.05)$.

\section{Results}

In 2011, black shank disease incidence in the nontreated control plots reached $53.0 \%$. All of the treatments reduced disease significantly $(P=0.05)$ compared with the nontreated control (Table 1). Two treatments were the most effective: (i) application of Zorvec through transplant water ( 0.35 liter/ha) and at first cultivation and lay-by (2.8 liter/ha); and (ii) application of Zorvec prior to transplanting (0.35 liter/ha) and at first cultivation and lay-by (1.4 liter/ha). These two treatments were more effective than Ridomil Gold in disease reduction and increased tobacco yield significantly compared with the nontreated control. Application of Zorvec prior to transplanting (0.35 liter/ha) and at first cultivation and lay-by ( 0.35 to 1.4 liter/ha) appeared to be numerically more effective than band application 7 days after transplanting plus directed spray

Table 1. Efficacy of Zorvec for reduction of black shank of tobacco under field conditions (2011)

\begin{tabular}{|c|c|c|c|c|}
\hline Treatment & Rate (liter/ha) & Application schedule ${ }^{w, x}$ & Tobacco yield $(\mathrm{kg} / \mathrm{ha})^{\mathrm{w}, \mathrm{y}}$ & Disease incidence $(\%)^{\mathrm{w}, \mathrm{z}}$ \\
\hline Zorvec & $\begin{array}{l}0.35 \\
2.80 \\
2.80\end{array}$ & $\begin{array}{l}\text { Tray drench } \\
\text { First cultivation } \\
\text { Lay-by }\end{array}$ & $3,309 \mathrm{ab}$ & $9.5 \mathrm{bc}$ \\
\hline Zorvec & $\begin{array}{l}0.35 \\
1.40 \\
1.40\end{array}$ & $\begin{array}{l}\text { Tray drench } \\
\text { First cultivation } \\
\text { Lay-by }\end{array}$ & $3,277 \mathrm{abc}$ & $8.3 \mathrm{c}$ \\
\hline Zorvec & $\begin{array}{l}0.35 \\
0.70 \\
0.70\end{array}$ & $\begin{array}{l}\text { Tray drench } \\
\text { First cultivation } \\
\text { Lay-by }\end{array}$ & $2,469 \mathrm{bc}$ & $20.8 \mathrm{bc}$ \\
\hline Zorvec & $\begin{array}{l}0.35 \\
0.35 \\
0.35\end{array}$ & $\begin{array}{l}\text { Tray drench } \\
\text { First cultivation } \\
\text { Lay-by }\end{array}$ & $2,837 \mathrm{bc}$ & $11.9 \mathrm{bc}$ \\
\hline Zorvec & $\begin{array}{l}2.80 \\
1.40 \\
1.40\end{array}$ & $\begin{array}{l}\text { Band application } \\
\text { First cultivation } \\
\text { Lay-by }\end{array}$ & $3,053 \mathrm{abc}$ & $18.2 \mathrm{bc}$ \\
\hline Zorvec & $\begin{array}{l}2.80 \\
0.70 \\
0.70\end{array}$ & $\begin{array}{l}\text { Band application } \\
\text { First cultivation } \\
\text { Lay-by }\end{array}$ & $2,403 \mathrm{~cd}$ & $28.2 \mathrm{~b}$ \\
\hline Zorvec & $\begin{array}{l}2.80 \\
0.35 \\
0.35\end{array}$ & $\begin{array}{l}\text { Band application } \\
\text { First cultivation } \\
\text { Lay-by }\end{array}$ & $3,154 \mathrm{abc}$ & $15.7 \mathrm{bc}$ \\
\hline Zorvec & $\begin{array}{l}0.35 \\
2.80 \\
2.80\end{array}$ & $\begin{array}{l}\text { Transplant water } \\
\text { First cultivation } \\
\text { Lay-by }\end{array}$ & 3,864 a & $2.2 \mathrm{c}$ \\
\hline Ridomil Gold & $\begin{array}{l}1.17 \\
1.17 \\
1.17\end{array}$ & $\begin{array}{l}\text { Band application } \\
\text { First cultivation } \\
\text { Lay-by }\end{array}$ & $2,619 \mathrm{bc}$ & $28.0 \mathrm{~b}$ \\
\hline Nontreated control & $\ldots$ & $\ldots$ & $1,741 \mathrm{~d}$ & $53.0 \mathrm{a}$ \\
\hline
\end{tabular}

${ }^{w}$ Data are means of five replications. Means in a column followed by the same letters are not significantly different $(P=0.05)$ according to Fisher's least significant difference.

${ }^{\mathrm{x}}$ Tray drench was conducted by spray in greenhouse 1 week before transplanting into the field. Tobacco was transplanted on 11 April. First cultivation and lay-by were conducted on 2 May and 19 May, respectively. Band application was made 7 days after transplanting using a $\mathrm{CO}_{2}$-powered sprayer. Application through transplant water was made at transplanting using a $\mathrm{CO}_{2}$-powered sprayer delivering the chemical directly into the transplant water and plant furrow.

${ }^{y}$ Dry weight yield of tobacco which was calculated by multiplying green weight by 0.15 .

${ }^{\mathrm{z}}$ Final disease incidence (\% diseased plants). 
at first cultivation and lay-by. There was no significant difference in disease reduction among the treatments when Zorvec was applied prior to transplanting ( 0.35 liter/ha) and at first cultivation and lay-by at $0.35,0.7,1.4$, and 2.8 liter/ha (Table 1 ).

In 2012, final disease incidence in the nontreated control plots was very high (97.3\%). Similar to the 2011 field study, Zorvec applied prior to transplanting (0.35 liter/ha) and at first cultivation and lay-by (0.7 liter/ha) reduced disease and increased tobacco yield significantly $(P=0.05)$ compared with the nontreated control (Table 2). All other treatments also reduced disease and increased tobacco yield significantly, compared to the nontreated control, except Zorvec applied through transplant water ( 0.7 liter/ha) only. Application of Zorvec through transplant water (1.4 liter/ha) plus at first cultivation and lay-by (0.7 liter/ha), and application of the product prior to transplanting ( 0.35 liter/ha) plus at first cultivation and lay-by (0.7 liter/ha), were not significantly different in disease reduction compared with Ridomil Gold. Combined use of Zorvec (through transplant water at 0.7 liter/ha) and Ridomil Gold (at first cultivation and lay-by at 1.17 liter/ha) was not significantly different in disease reduction compared to application of Ridomil Gold alone.

In 2013, application of Zorvec through transplant water (2.8 liter/ha), or Zorvec applied through transplant water (1.4 liter/ha) and at first cultivation and lay-by, reduced disease significantly $(P$ $=0.05$ ) compared with the nontreated control and showed a tendency to increase tobacco yield (Table 3). Ridomil Gold applied through transplant water and at first cultivation and lay-by also reduced disease significantly compared to the nontreated control.

\section{Discussion}

Georgia is among the top five states in the United States in tobacco production with more than 6,000 ha of tobacco produced in the state in 2013 (22). In the United States, black shank was first reported in Georgia in 1915 (14) and has been a continuous threat to tobacco production $(4,5,8)$. The limitations of traditional approaches for control of black shank necessitate the exploration of alternative or complementary control methods such as new chemical fungicides. In this report, field studies conducted in 2011 to 2013 indicated that black shank on tobacco was significantly reduced by Zorvec that could be used as a promising component in developing integrated programs for effective management of the disease.

Different rates and application methods of Zorvec were evaluated in the study. Treatment of tobacco seedlings with Zorvec $(0.35$ liter/ha) 1 week prior to transplanting into the field combined with

Table 2. Efficacy of Zorvec for reduction of black shank of tobacco under field conditions (2012)

\begin{tabular}{|c|c|c|c|c|}
\hline Treatment & Rate (liter/ha) & Application schedule ${ }^{w, x}$ & Tobacco yield $(\mathrm{kg} / \mathrm{ha})^{\mathrm{w}, \mathrm{y}}$ & Disease incidence $(\%)^{\mathrm{w}, \mathrm{z}}$ \\
\hline Zorvec & $\begin{array}{l}0.35 \\
0.70 \\
0.70\end{array}$ & $\begin{array}{l}\text { Tray drench } \\
\text { First cultivation } \\
\text { Lay-by }\end{array}$ & $2,648 \mathrm{abc}$ & $37.0 \mathrm{bc}$ \\
\hline Zorvec & 2.80 & Transplant water & $1,992 \mathrm{~cd}$ & $57.7 \mathrm{~b}$ \\
\hline Zorvec & 1.40 & Transplant water & $1,903 \mathrm{~d}$ & $60.8 \mathrm{~b}$ \\
\hline Zorvec & 0.70 & Transplant water & $1,177 \mathrm{e}$ & $87.6 \mathrm{a}$ \\
\hline Zorvec & $\begin{array}{l}1.40 \\
0.70 \\
0.70\end{array}$ & $\begin{array}{l}\text { Transplant water } \\
\text { First cultivation } \\
\text { Lay-by }\end{array}$ & 2,405 a-d & $38.9 \mathrm{bc}$ \\
\hline Zorvec & $\begin{array}{l}0.70 \\
0.70 \\
0.70\end{array}$ & $\begin{array}{l}\text { Transplant water } \\
\text { First cultivation } \\
\text { Lay-by }\end{array}$ & $2,197 \mathrm{bcd}$ & $52.8 \mathrm{~b}$ \\
\hline Zorvec & 0.70 & Transplant water & & \\
\hline Ridomil Gold & $\begin{array}{l}1.17 \\
1.17\end{array}$ & $\begin{array}{l}\text { First cultivation } \\
\text { Lay-by }\end{array}$ & 3,068 a & $22.3 \mathrm{c}$ \\
\hline Ridomil Gold & $\begin{array}{l}0.58 \\
1.17 \\
1.17\end{array}$ & $\begin{array}{l}\text { Transplant water } \\
\text { First cultivation } \\
\text { Lay-by }\end{array}$ & $2,905 \mathrm{ab}$ & $18.9 \mathrm{c}$ \\
\hline Nontreated control & $\ldots$ & $\ldots$ & $565 \mathrm{e}$ & $97.3 \mathrm{a}$ \\
\hline
\end{tabular}

${ }^{\mathrm{w}}$ Data are means of five replications. Means in a column followed by the same letters are not significantly different $(P=0.05)$ according to Fisher's least significant difference.

${ }^{\mathrm{x}}$ Tray drench was conducted by spray in greenhouse 1 week before transplanting into the field. Tobacco was transplanted on 30 March. First cultivation and lay-by were conducted on 25 April and 9 May, respectively. Application through transplant water was made at transplanting using a $\mathrm{CO}_{2}$-powered sprayer delivering the chemical directly into the transplant water and plant furrow.

${ }^{\mathrm{y}}$ Dry weight yield of tobacco which was calculated by multiplying green weight by 0.15 .

${ }^{\mathrm{z}}$ Final disease incidence (\% diseased plants).

Table 3. Efficacy of Zorvec for reduction of black shank of tobacco under field conditions (2013)

\begin{tabular}{|c|c|c|c|c|}
\hline Treatment & Rate (liter/ha) & Application schedule ${ }^{w, x}$ & Tobacco yield $(\mathrm{kg} / \mathrm{ha})^{\mathrm{w}, \mathrm{y}}$ & Disease incidence $(\%)^{\mathrm{w}, \mathrm{z}}$ \\
\hline Zorvec & 2.80 & Transplant water & $1,786 \mathrm{ab}$ & $47.4 \mathrm{~b}$ \\
\hline Zorvec & $\begin{array}{l}1.40 \\
0.70 \\
0.70\end{array}$ & $\begin{array}{l}\text { Transplant water } \\
\text { First cultivation } \\
\text { Lay-by }\end{array}$ & $1,748 \mathrm{ab}$ & $46.2 \mathrm{~b}$ \\
\hline Ridomil Gold & $\begin{array}{l}0.58 \\
1.17 \\
1.17\end{array}$ & $\begin{array}{l}\text { Transplant water } \\
\text { First cultivation } \\
\text { Lay-by }\end{array}$ & $2,109 \mathrm{a}$ & $50.2 \mathrm{~b}$ \\
\hline Nontreated control & $\ldots$ & $\ldots$ & $1,312 \mathrm{~b}$ & $79.5 \mathrm{a}$ \\
\hline
\end{tabular}

${ }^{\mathrm{w}}$ Data are means of five replications. Means in a column followed by the same letters are not significantly different $(P=0.05)$ according to Fisher's least significant difference.

${ }^{\mathrm{x}}$ Tobacco was transplanted in the field on 10 April. First cultivation and lay-by were conducted on 9 May and 24 May, respectively. Application through transplant water was made at transplanting using a $\mathrm{CO}_{2}$-powered sprayer delivering the chemical directly into the transplant water and plant furrow.

${ }^{\mathrm{y}}$ Dry weight yield of tobacco which was calculated by multiplying green weight by 0.15 .

${ }^{\mathrm{z}}$ Final disease incidence (\% diseased plants). 
directed sprays at first cultivation and lay-by showed to be effective in reduction of black shank in 2011. Application rates ranging from 0.35 to 2.8 liter/ha for directed sprays at first cultivation and lay-by did not result in significant difference in disease reduction. A moderate rate $(0.7$ liter/ha) of Zorvec was further evaluated for directed sprays at first cultivation and lay-by in 2012, which reduced disease and increased tobacco yield significantly when used in combination with treatment of tobacco seedlings prior to transplanting, indicating this treatment was consistent in reduction of black shank. Another treatment that reduced disease significantly was application of Zorvec through transplant water (1.4 liter/ha) in conjunction with directed sprays at first cultivation and lay-by $(0.7$ liter/ha). This treatment was about equally effective in disease reduction and yield increase compared to application of Zorvec at 0.35 liter/ha in the greenhouse in conjunction with sprays at first cultivation and lay-by at 0.7 liter/ha (Table 2). Further evaluation of this treatment in the 2013 study resulted in significant disease reduction as well. Application of Zorvec at a higher rate (2.8 liter/ha) through transplant water only also reduced disease significantly in both 2012 and 2013 experiments, but was relatively less effective (average disease reduction $40.5 \%$ ) compared to application of Zorvec through transplant water (1.4 liter/ha) in conjunction with directed sprays at first cultivation and lay-by at 0.7 liter/ha (average disease reduction 51.0\%).

Oxathiapiprolin is the first member of a new class of isoxazoline fungicide that acts at a unique site of action in oomycete pathogens (17). It has an effect on all stages of oomycete pathogen development at very low concentrations (17). Mefenoxam belongs to another fungicide class with a different mode of action, disrupting nucleic acid synthesis of oomycete pathogens (12). It was active in suppressing mycelial growth and formation of sporangia of $P$. nicotianae (20). In the present study, application of mefenoxam reduced black shank and increased tobacco yield significantly in the experiments conducted in 3 years, which was in agreement with previous studies that reported the efficacy of mefenoxam to control black shank (6-8). Csinos and Minton (8) reported that metalaxyl (a.i. mefenoxam) when preplant incorporated reduced black shank on tobacco. Metalaxyl when applied preplant incorporated and at lay-by was effective in reducing black shank, while methyl bromide injected into the soil prior to transplanting did not reduce the disease significantly (7). In another study, application of metalaxyl through irrigation water was equally effective and more economical at reducing black shank than application with tractor-powered equipment (6). Isolates of $P$. nicotianae resistant to mefenoxam have not been reported; however, continuous use of the product may result in reduced sensitivity of $P$. nicotianae populations. Studies (18) indicated that there was an apparent response to the selection pressure applied by repeated use of metalaxyl. $\mathrm{ED}_{50}$ values (fungicide concentrations resulted in $50 \%$ reduction) for isolates of $P$. nicotianae collected after 2 and 3 years of metalaxyl exposure under field conditions increased twofold and threefold, respectively. Hence, identification of new effective fungicides such as oxathiapiprolin to be used as an alternative or complementary approach is desirable. For example, use of oxathiapiprolin in rotation with mefenoxam or tank-mix application of the products may reduce selection pressure and the development of fungicide resistance.

In this study, oxathiapiprolin was effective in reduction of black shank on tobacco. Specifically, spray with Zorvec at 0.35 liter/ha for soil and root drench prior to transplanting and directed sprays at 0.7 liter/ha at first cultivation and lay-by, as well as application through transplant water (1.4 liter/ha) and sprays at first cultivation and lay-by (0.7 liter/ha), reduced black shank significantly in repeated field experiments. All the application methods used in the studies are practically acceptable by growers in commercial tobacco production in the southeastern United States. Hence, oxathiapiprolin could be readily incorporated into black shank management practices in commercial tobacco production. The potential of $P$. nicotianae populations to develop resistance to oxathiapipro- lin is unknown. Further studies could be conducted to determine sensitivity of $P$. nicotianae isolates from different geographical locations to the compound and monitor potential fungicide resistance development. In addition, integrated disease management programs incorporating oxathiapiprolin and other approaches such as resistant tobacco cultivars could be developed for the possibility of enhancing disease control efficacy. Such studies may provide a more comprehensive understanding of the role of oxathiapiprolin in managing black shank in tobacco production.

\section{Acknowledgments}

We thank DuPont Crop Protection for providing oxathiapiprolin for the study, and support by Georgia Agricultural Commodity Commission for Tobacco is appreciated.

\section{Literature Cited}

1. Antonopoulos, D. F., Melton, T., and Mila, A. L. 2010. Effects of chemical control, cultivar resistance, and structure of cultivar root system on black shank incidence of tobacco. Plant Dis. 94:613-620.

2. Apple, J. L. 1962. Physiological specialization within Phytophthora parasitica var. nicotianae. Phytopathology 52:351-354.

3. Csinos, A. S. 1999. Stem and root resistance to tobacco black shank. Plant Dis. 83:777-780.

4. Csinos, A. S. 2005. Relationship of isolate origin to pathogenicity of race 0 and 1 of Phytophthora parasitica var. nicotianae on tobacco cultivars. Plant Dis. 89:332-337.

5. Csinos, A. S., and Bertrand, P. F. 1994. Distribution of Phytophthora parasitica var. nicotianae races and their sensitivity to metalaxyl in Georgia. Plant Dis. 78:471-474.

6. Csinos, A. S., Johnson, A. W., and Golden, A. M. 1986. Metalaxyl and fenamiphos applied through irrigation water to control black shank/rootknot complex on tobacco. Plant Dis. 70:210-213.

7. Csinos, A. S., Johnson, A. W., and Golden, A. M. 1994. Management of the tobacco black shank-root-knot complex with combinations of soil fumigants and metalaxyl. Plant Dis. 78:565-568.

8. Csinos, A. S., and Minton, N. A. 1983. Control of tobacco black shank with combinations of systemic fungicides and nematicides or fumigants. Plant Dis. 67:204-207.

9. Gallegly, M. E., and Hong, C. 2008. Phytophthora: Identifying species by morphology and DNA fingerprints. American Phytopathological Society, St. Paul, MN

10. Gallup, C. A., and Shew, H. D. 2010. Occurrence of race 3 of Phytophthora nicotianae in North Carolina, the causal agent of black shank of tobacco. Plant Dis. 94:557-562.

11. Jeffers, S. N., and Martin, S. B. 1986. Comparison of two media selective for Phytophthora and Pythium species. Plant Dis. 70:1038-1043.

12. Kuck, K.-H., and Gisi, U. 2008. FRAC mode of action classification an resistance risk of fungicides. Pages 415-432 in: Modern Crop Protection Compounds. W. Krämer and U. Schirmer, eds. Wiley-VCH Verlag GmbH \& Co. KGaA, Weinheim, Germany.

13. Lamprecht, M. P., Prinsloo, G. C., and van Wyk, R. J. 1974. Inheritance of resistance to race 2 of the black shank fungus, Phytophthora nicotianae (B de Haan) var. nicotianae, of tobacco. Agroplantae 6:73-76.

14. Lucas, G. B. 1975. Diseases of Tobacco. 3rd ed. Biological Consulting Associates, Raleigh, NC.

15. McIntyre, J. L., and Taylor, G. S. 1978. Race 3 of Phytophthora parasitica var. nicotianae. Phytopathology 68:35-38.

16. Parkunan, V., Johnson, C. S., Bowman, B. C., and Hong, C. X. 2010. Population structure, mating type, and mefenoxam sensitivity of Phytophthora nicotianae in Virginia tobacco fields. Plant Dis. 94:1361-1365.

17. Shepherd, C. P., Bruhn, J. A., Carski, T. H., Summers, B., Hoffman, L. E. Perotin, B., and Sweigard, J. A. 2013. DuPont ${ }^{\mathrm{TM}}$ Zorvec $^{\mathrm{TM}}$ (DPX-QGU42, oxathiapiprolin): The first member of a novel class of Oomycete fungicides. Page 17 in: Abstr. 4th Int. Phytophthora capsici Conf. A. Csinos and P. D. Roberts, eds.

18. Shew, H. D. 1985. Response of Phytophthora parasitica var. nicotianae to metalaxyl exposure. Plant Dis. 69:559-562.

19. Shew, H. D., and Lucas, G. B. 1991. Compendium of Tobacco Diseases. American Phytopathological Society, St. Paul, MN.

20. Staub, T. H., and Young, T. R. 1980. Fungitoxicity of metalaxyl against Phytophthora parasitica var. nicotianae. Phytopathology 70:797-801.

21. Sullivan, M. J., Melton, T. A., and Shew, H. D. 2005. Managing the race structure of Phytophthora parasitica var. nicotianae with cultivar rotation. Plant Dis. 89:1285-1294.

22. U.S. Dep. Agric.-Nat. Agric. Stat. Serv. 2013. Agricultural Statistics - Field crops. Accessed online http://www.nass.usda.gov/

23. van Jaarsveld, E., Wingfield, M. J., and Drenth, A. 2002. Evaluation of tobacco cultivars for resistance to races of Phytophthora nicotianae in South Africa. J. Phytopathol. 150:456-462.

24. Waterhouse, G. 1963. Key to the species of Phytophthora de Bary. Mycological Papers, No. 92. Commonwealth Mycological Society, Kew, England. 